\title{
„Új” Schotte-Gönczy-glóbuszok, valamint aukciókon vagy hirdetésekben felbukkant Gönczy Pál szerkesztette földgömbök
}

\author{
MÁRTON Mátyás - TORONYI Bence
}

DOI: $10.30921 / G K .73 .2021 .6 .2$

Absztrakt: Jelen tanulmány egy három cikkból álló sorozat harmadik tagja, amelyben a szerzök bemutatják a 2017 óta látókörükbe került új - a szakirodalomban ismeretlen - glóbuszokat, amelyek magyar nyelvú változatát Gönczy Pál szerkesztette.

A szerzök részletekbe menóen mutatnak be két 23,7 cm és egy 32,9 cm átmérójü, Gönczy magyaritotta és a berlini Ernst Schotte cég által kiadott glóbuszt.

A tanulmány második részében a szerzök aukciókon és hirdetésekben felbukkant földgömböket mutatnak be. Két 21,7 cm átmérôjū prágai Felkl-glóbuszt ismerhetünk meg. Ezek egyike elsố kiadású ebböl a földgömbfajtából. Bemutatásra kerül kétféle 31,6 cm-es, Felkl és fia által a Prága melletti Roztokban kiadott glóbusz második, javított kiadása, valamint a legszebb állapotban fennmaradt magyar nyelvú 47,5 cm-es Felkl-glóbusz is, Prágából.

Abstract: This paper is the third one in a series of three articles in which the authors present the new globes that have come to their attention since 2017 and are unknown in the literature. Their Hungarian version was edited by Pál Gönczy.

The authors present in detail two globes of $23.7 \mathrm{~cm}$ and one of $32.9 \mathrm{~cm}$ in diameter translated into Hungarian by Gönczy and published by Ernst Schotte in Berlin.

In the second part of this paper the authors present globes which appeared in auctions or advertisement. Two Felkl globes of $21.7 \mathrm{~cm}$ in diameter are presented from Prague. One of them is the first edition of this kind of earth globes. Two kinds of the revised second edition of the $31.8 \mathrm{~cm}$ diameter globe from Roztok near Prague from Felkl and his son, and a Hungarian-language Felkl globe of $47.5 \mathrm{~cm}$ in diameter from Prague in the most beautiful condition are also described.

Kulcsszavak: magyar nyelvú glóbuszok Berlinből; egy glóbuszgyártó múhely: Ernst Schotte Berlinben; aukciókon és hirdetésekben felbukkant Gönczy magyarította földgömbök a prágai Felkl, valamint a Felkl és fia cégtől a prága melletti Roztokból; Virtuális Glóbuszok Múzeuma

Keywords: Hungarian-language globes from Berlin; a globe making factory: Ernst Schotte in Berlin; globes appeared in auctions or advertisement translated into Hungarian by Gönczy from Felkl in Prague and Felkl and son in Roztok near Prague; Virtual Globes Museum

\section{Bevezetés}

Plihál Katalin 2016-ban megjelent, nyomtatott, magyar nyelvú föld- és éggömbökkel foglalkozó nagy összefoglaló munkáját követôen „sem állt le az élet”. Újra meg újra előkerülnek ezen érzékeny mútárgyaknak „túlélő” darabjai, s egy-egy glóbusz olyan kiadásaival, olyan példányaival találkozhatunk, amelyeket korábban nem ismertünk, vagy létezésüket csak feltételezhettük.

Cikksorozatunknak ebben a (záró) részében „új”, utóbb felfedezett, Berlinben kiadott Schotte-Gönczyglóbuszokkal foglalkozunk. Majd bemutatunk néhány „elérhetetlen”, aukciókon vagy hirdetésekben feltúnt Gönczy-földgömböt is.

Gönczy Pál berlini kapcsolatainak feltárásában biztos pontot jelent az, hogy az Akadémiai Almanach Gönczybibliográfiájában „Schotte sima és domború földgömbjei különféle átmérökkel. Berlin, 1872.” szerepel (MTA Alm. 1892, p. 137.). Megerôsíti ezt a Szinnyei-féle (1894, pp. 1364-1365.) Gönczy-bibliográfia is, de utóbbiban szerepel a „Tellurium Planetarium. Berlin, 1872." a felsorolt múvek között, míg az Almanachban nem. (Láthatjuk, hogy a két bibliográfia nem azonos.) Meg kell azonban mondani, hogy erről az oktatási szemléltetôeszközrôl, illetve a domború földgömbökrôl semmit nem tudunk. Ugyanakkor fontos tény az is, hogy egyik bibliográfia sem említi a glóbuszok késôbbi kiadását, kiadásait.

\section{Korábban ismeretlen} 23,7 cm átmérôjuú SchotteGönczy-glóbusz Korányi G. Tamás gyújiteményében

„Rokona” a Virtuális Glóbuszok Múzeumában feldolgozott VGM ID 99 azonosítójú földgömbnek. Ez a legépebben fennmaradt az ismert példányok közül. Szépsége Lente Zsuzsanna 2020-ban végzett értố restaurátori munkájának is köszönhetô. Feldolgozása a Virtuális Glóbuszok számára még nem történt meg.

$23,7 \mathrm{~cm}$ (9 bécsi hüvelyk) átmérôjú, 1 : 53839000 méretarányú politikai-domborzati földgömb. Egyenlitöi kerülete: $74,44 \mathrm{~cm}$.

Színes országhatárbandos, lejtốcsíkozásos domborzatrajzú, 1878-ban vagy az után kiadott földgömb, párhuzamos vonalfonatokkal jelölt tengeráramlás-ábrázolással, áramlásnevekkel. Ferrói kezdômeridián, és innen kelet felé $360^{\circ}$-ig haladva $10^{\circ}$-onként megírt hosszúsági körök, valamint jó állásban megrajzolt Ekliptika jellemzik. A kolofon: „A legujabb (!) és legjobb forrá (!) | sok szerint készitett (!) | FỐLDGÖMB (!) | magyaritotta (!) | Gönczy Pál | kiadja | Schotte Ernô és társa | BERLINBEN.” A Gönczy által magyarított 23,7 cm-es földgömbök 
közül (Románia ábrázolása szerint) minden bizonnyal 1878-as vagy az utáni kiadású!

\section{A glóbusz térképi}

\section{tartalmának jellemzói}

- A vetület: valószínúsíthetôen meridiánokban és Egyenlítőben hossztartó hengervetület („négyzetes hengervetület") transzverzális elhelyezésú változata a $30^{\circ}$-os gömbszegmensek, illetve Postel-féle meridiánban hossztartó síkvetület a $10^{\circ}$-os pólustávolságú pólussapkák elkészítéséhez.

- Ferrói kezdômeridián.

- A vékony, folyamatos vonallal megrajzolt $10^{\circ}$-os beosztású fokhálózat, a szaggatott vonalú térítôk és sarkkörök ábrázolásával egészül ki. Az Egyenlítô és a $0^{\circ}$-os (kezdō-)

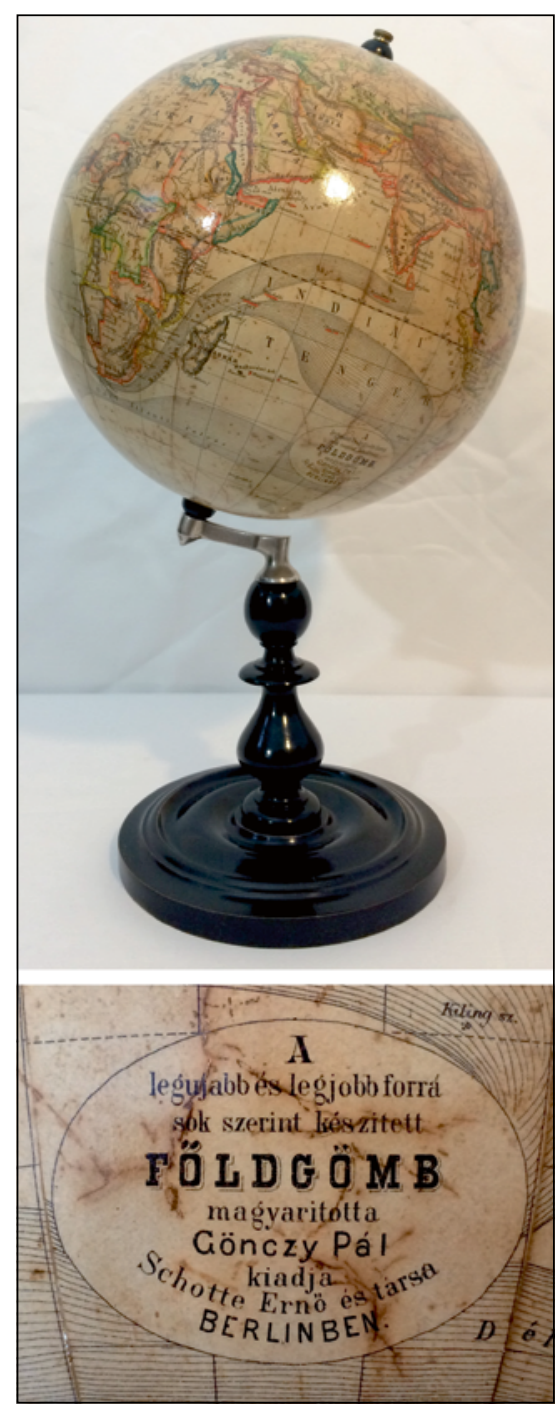

1. ábra. A Schotte-Gönczy-glóbusz és kolofonja Korányi G. Tamás szivességébôl. Fotók: Lente Zsuzsanna meridián, valamint az Ekliptika (az égi egyenlítô) kiemelt, ún. létrás ábrázolású.

- A kontinensek és a jelentôsebb szigetek partvonalán túl a vízrajz a nagyobb folyókat és ezek fóbb mellékfolyóit, valamint a legjelentősebb tavakat (mélységábrázolás nélkül) tartalmazza.

- A szárazföldi területeken világosokker felületi színezés és barna lejtőcsíkozásos domborzatábrázolás található.

- Az országhatárok szaggatott vonallal és/vagy mellette húzódó színes határbanddal jelöltek.

- A településábrázolás kategorizált (kétféle jelet - nagyobb és kisebb átmérôjú üres karika - különböztet meg). A megírásban is két kategória szerepel: álló félkövér kurrens (nagy kezdőbetûs) írás, pl.: Berlin, Bécs, Pest, Konstánczinápoly, valamint normál kurrens kurzív (dôlt) írás, pl.: Stettin, Königsberg, Buda.

- A névrajz az oktatási célnak megfelelően magyar. A már említett településmegírásokon túl a névrajzi elemek között szerepel az országok (a tagállamok), a legfontosabb szigetek, földfokok, a legjelentôsebb hegységek neve, valamint vízfolyások, tavak és az óceánok, tengerek, jelentôsebb tengeröblök, tengerszorosok nevei, illetve a tengeráramlások megírásai. Az Egyenlítô, a térítôk, a sarkkörök megnevezése is megtalálható. A fokszámok közül a hosszúsági értékek ( $10^{\circ}$-onként $0^{\circ}$-tól $360^{\circ}$-ig számozva!) az Egyenlítôn, a szélességi értékek a kezdőmeridiánon vannak megírva. A névrajzi elemek között nem szerepelnek a kontinensnevek.

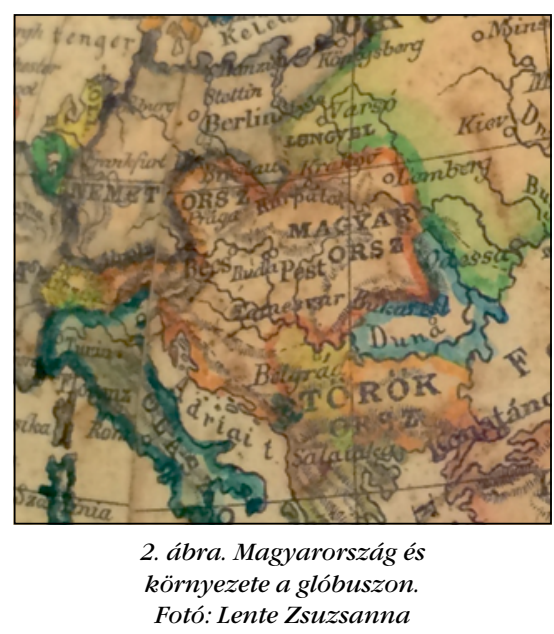

- A tengerek területe fehér színú, amelyen vékony fekete vonalkötegek mutatják a tengeráramlásokat, igen ritkán az irány (nyíl) megadásával! Vízmélységadatokat nem találunk. Az óceánok megnevezése „tenger” földrajzi köznévi utótaggal történik (INDIAI TENGER).

- A nyomási színek száma nyolc: fekete, okker, szürkéslila, világoskék, vörös, narancs, sárga és zöld.

- Fekete: a fokhálózat, a partvonal, a vízrajz és a tengeráramlások rajzolata, az összes névrajzi elem, ide értve a kolofont is, valamint a csíkozásos domborzatábrázolás.

- Okker: a szárazföldi területek (alapszín).

- Szürkéslila: a határbandok.

- Világoskék: a vízfelületek (tavak), határbandok.

- Vörös: a határbandok.

- Narancs: a határbandok.

- Sárga: a határbandok.

- Zöld: a határbandok.

\section{A 23,7 cm átmérójú Schotte-Gönczy- glóbusz elsố kiadása a Göcseji Múzeumban}

A földgömb a zalaegerszegi Göcseji Múzeum gyújteményéhez 2021-ben került a Nemzeti Kulturális Alap támogatásával megvásárolt Oláh Dénes ügyvéd hagyatékának részeként. Leltári száma: TOT_2021.3.1. Megyeri Anna történész fômuzeológus szívességébôl jutottunk a földgömbleírást lehetôvé tevô nagy felbontású fényképfelvételekhez, amelyeket Bicskei József készített. A gömb „rokona” a Virtuális Glóbuszok Múzeuma (VGM) ID 99 azonosítójú darabjának, a Császi-gyújteményből. A Gönczy által magyarított 23,7 cm-es Schotte-földgömbök elsố kiadásának jó állapotban fennmaradt példányáról van szó, amelynek különlegessége az a fémból készült állvány, amelyet minden valószínúség szerint a korábbi tulajdonos, Oláh Dénes készíttetett.

$23,7 \mathrm{~cm}$ (9 bécsi hüvelyk) átmérốjú, 1 : 53839000 méretarányú domborzati-politikai földgömb. Egyenlítôi kerülete: $74,44 \mathrm{~cm}$.

Lejtốcsíkozásos domborzatrajzú, széles kontinenshatárbandos, szaggatott vonallal megrajzolt, esetenként 
banddal is kiemelt országhatárrajzos, feltehetốen 1872-ben kiadott földgömb, párhuzamos vonalfonatokkal jelölt tengeráramlás-ábrázolással, áramlásnevekkel. Ferrói kezdômeridián, és innen kelet felé $360^{\circ}$-ig haladva $10^{\circ}$ onként megírt hosszúsági körök, valamint jó állásban megrajzolt Ekliptika jellemzik. A kolofon: „A | legujabb (!) és legjobb forrá (!) | sok szerint készitett (!) | FỐLDGÖMB (!) | magyaritotta (!) | Gönczy Pál | kiadja | Schotte Ernô és társa | BERLINBEN."

Ismeretlen (nem jelölt) évszámú kiadás hordozógömbre kasírozott, állványra szerelt példánya.

A földgömb átfedôsávval bóvített $30^{\circ}$-os, papírra nyomtatott gömbszegmensek hordozógömbre kasírozásával készült, $12 \mathrm{db}$ - a sarkoknál csonkolt gömbkétszögból áll, $10^{\circ}$-os pólustávolságú pólussapkákkal. A hordozógömb anyaga valószínúleg papírmasé, amelynek felületi egyenetlenségeit vékony gipszréteg felhordásával simították.

Az ún. teljes felszerelésú állványzat minden része fémból készült, valószínúleg a súlyosan megsérült eredeti pótlásaként. Ezért a horizontkörön nem találhatók meg a szokásos naptárkeret-beosztások, azonban a meridiánkör egyik oldala tartalmazza a fokbeosztást (mind a négy negyedben $1^{\circ}$-os beosztással, 10-tôl $90^{\circ}$-ig megírva). A meridiánkörhöz az északi pólusnál felszerelték a [félóránként (!) jelölt, egyóránként: 1-tôl 12-ig megírt (!)] valószínúleg eredeti órakört. (A horizontkört tartó egyik fémkar forrasztása sérült.)

Magassága: kb. 46,5 cm. (A horizontkör magassága: $32,8 \mathrm{~cm}$.)

\section{A glóbusz térképi tartalmának jellemzôi}

Sajnos a földgömbtérképet a Gönczy magyarította kiadás(ok) miatt nem frissítették a Schotte cégnél. Ez tapasztalható a „rokon” gömbökön is. Így szerepelhet rajta Dél-Amerikában Kolumbia helyett Új-Granada. Vagy inkább Gönczy se volt naprakész a politikai viszonyokat illetôen?! Hiszen a német kiadó csak azt a magyar
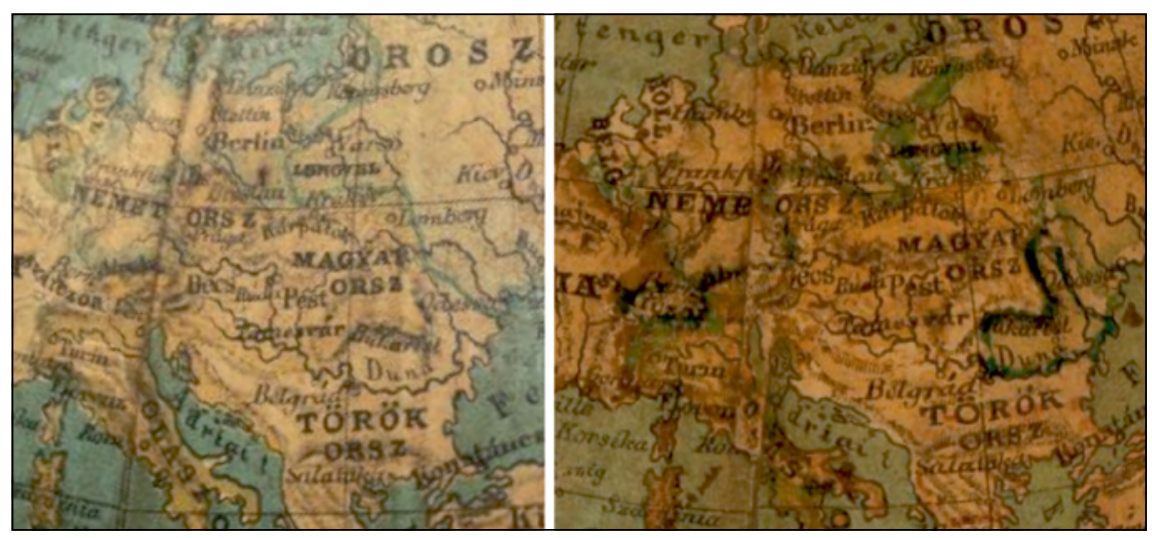

3. ábra. Magyarország és környezete

balra: a Göcseji Múzeum földgömbjén (fotó: Bicskei József), jobbra: a VGM ID 99 jelú glóbuszon (fotó: Nemes Zoltán).

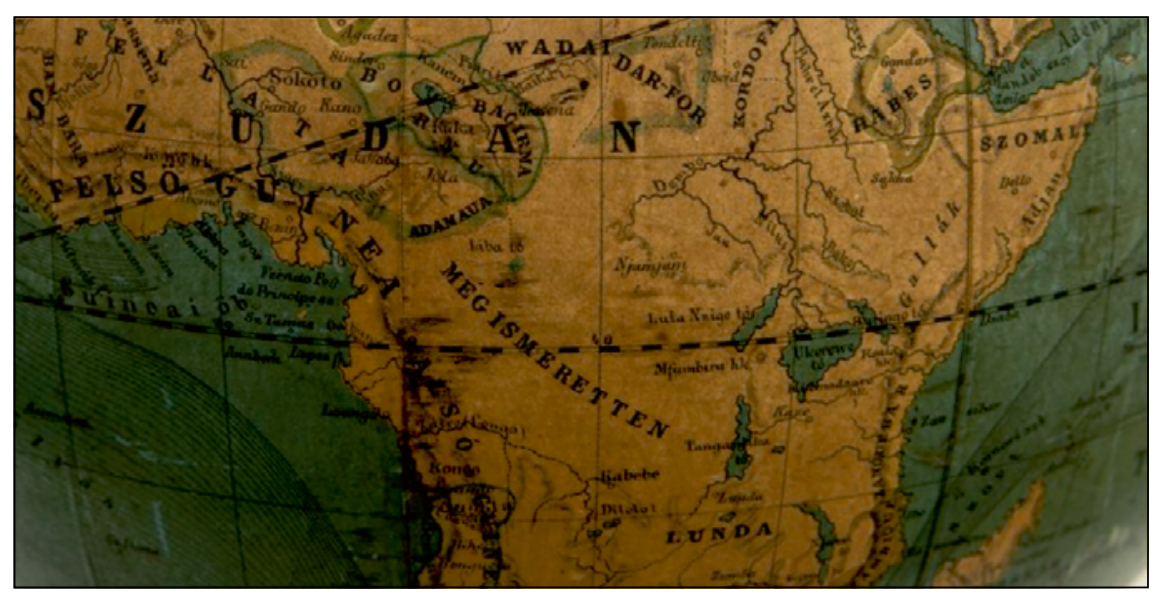

4. ábra. Afrika egyenlítôi vidéke a Göcseji Múzeum glóbuszán (fotó: Bicskei József)

szöveget szerkeszthette fel a glóbuszra, amit a magyar megrendelőtől kapott. Új-Granada területén Dél-Amerikában 1858-tól „Grenadine Confederation”, 1861-tôl „United States of New Granada”, 1863-tól „United States of Colombia”, 1886-tól „Republic of Colombia”, röviden és magyarul „Kolumbia” néven múködő ország volt, azaz semmiképpen nem helytálló az „Új-Granada” megnevezés.

A térképi tartalom (a színes országhatárbandoktól eltekintve) lényegében megegyezik az előzóekben ismertetett földgömbével, illetve a „rokonként” megjelölt, a Virtuális Glóbuszok Múzeumában is bemutatott VGM ID 99 azonosítójú glóbuszéval. Ahogyan azonban a korábbiakban is említettük, az azonos kolofon nem feltétlenül jelenti azt, hogy azonos kiadásról van szó, és nem jelenti a teljes tartalmi azonosságot sem. Esetünkben a határábrázolásban találhatunk lényeges eltéréseket. A 3. ábrán bal oldali ábrarész a most tárgyalt, míg a jobb oldali ábrarész a „rokon” gömb

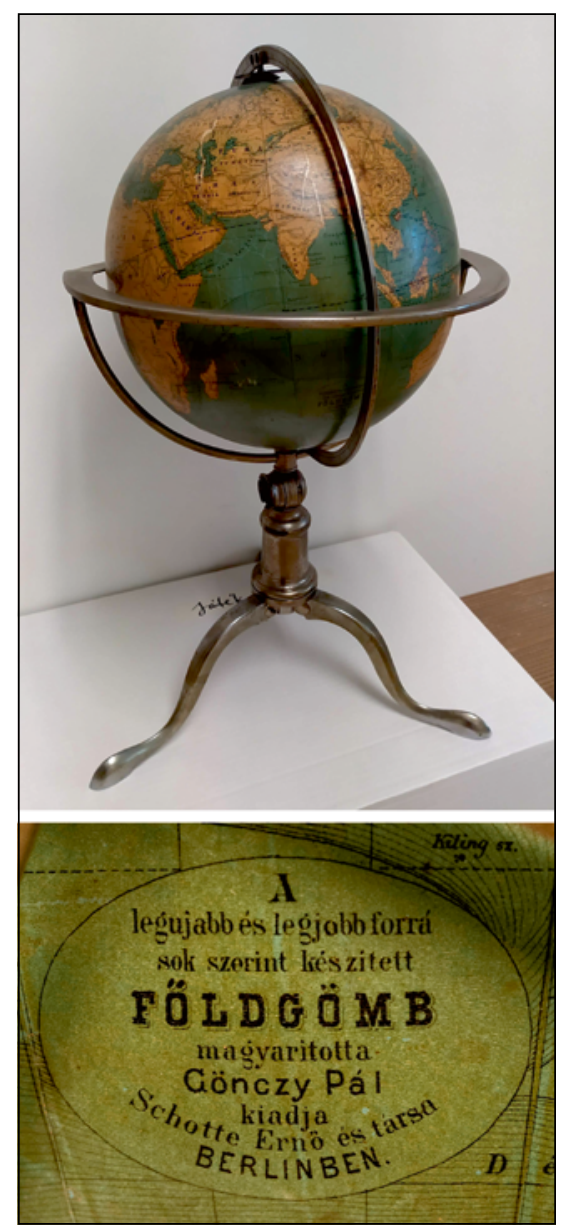

5. ábra. A 23, 7 cm-es földgömb a zalaegerszegi Göcseji Múzeum gyüjteményében. Megyeri Anna szivességéból. Fotók: Bicskei József. 
a 2. ábrán szereplő Magyarország környéki földgömbrészletének megfelelố kivágatot mutatja. Jól látható a határbandok eltérő megjelenése.

A 4. ábra megerôsíti az 1872-re tett kiadásiévszám-becslésünket, ugyanakkor a „MÉG ISMERETTEN” megírás Egyenlítôi-Afrika Ny felé esố részén jelzi a nem anyanyelvi térképíró személyét is.

\section{Eddig ismeretlen}

\section{2,9 cm-es Schotte-Gönczy- földgömb Toronyi Bence gyújteményében}

Lente Zsuzsanna restaurálta 2020-ban. A Virtuális Glóbuszok Múzeumában szereplő ID 158 azonosítójú feldolgozás a restaurálás elốtti állapotban készült.

$32,9 \mathrm{~cm}$ (12/1/2 bécsi hüvelyk) átmérójú, 1 :38 764000 méretarányú domborzati-politikai földgömb. Egyenlítôi kerülete: $103,38 \mathrm{~cm}$.

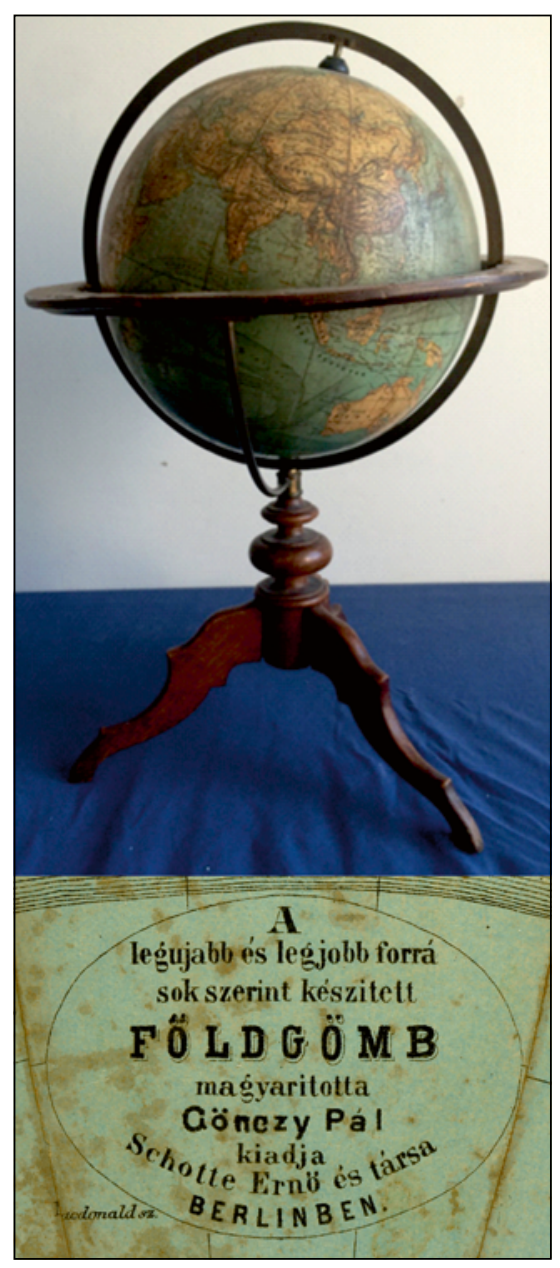

6. ábra. A 32,9 cm-es földgömb magángyüjteményben Dr. Toronyi Bence szívességébôl. Fotók: Toronyi Bence és Nemes Zoltán
Lejtốcsíkozásos domborzatábrázolású, visszafogott országhatárbandos, 1878 és 1884 között kiadott glóbusz, párhuzamos vonalfonatokkal jelölt, rajzos tengeráramlás-ábrázolással, áramlásnevekkel (az áramlásirányok nem jelöltek, tengermélységadatok nincsenek). Ferrói kezdőmeridián, jó állásban megrajzolt Ekliptika jellemzi. Kolofon: „A legujabb (!) és legjobb forrá (!) | sok szerint készitett (!) | FÔLDGÖMB (!) | magyaritotta (!) | Gönczy Pál | kiadja | Schotte Ernô és társa | BERLINBEN."

A földgömb szerkesztésének idejét 1878 és 1884 közé tesszük. A ferrói kezdômeridián szól az 1884 elôtti idôpont mellett, míg az 1878 vagy az utáni idôpontot a berlini kongresszuson született és 1878. július 13-án aláírt berlini szerzôdés dátuma adja. A szerződés értelmében Besszarábia déli része ekkor került vissza Oroszországhoz Romániától (az 1853 és 1856 között zajló krími háborút lezáró párizsi szerzôdés értelmében 1856 és 1878 között Moldvához tartozott). Ezt a terület a glóbuszon Oroszország részeként ábrázolták.

Valójában elmondhatjuk, hogy mindazok az elmarasztaló kijelentések, amelyek a későbbiekben odavezettek, hogy a földgömböket kitiltották az iskolai használatból (Plihál 2016, p. 121. és 133.), már az egészen korai idôszakban, az 1870-es években is jogosak lettek volna. Ha glóbuszunknak, csak hazánkat és szúkebb környezetét ábrázoló részét megvizsgáljuk, számos hibát találunk, ismerve, hogy 1878-ban vagy utána szerkesztették. Néhány szembeötlő példát említünk csupán:

- 1867-ben létrejött a kiegyezés. Ezért helytelen AUSZTRIA verzál megírása mellett Magyarorsz[ág] kurrens írásmódja, hiszen így a tartományokat jelölték, lásd a Galiczia (értsd: Galíczia) megírást például.

- 1873. január 1-jétôl Pest és Buda (valamint Óbuda) egyesült. 1878-ban tehát már a Budapest megírásnak kellett volna szerepelnie a glóbuszon.

- 1878-ban - ugyanazon berlini szerzôdés szerint, ami az alsó idôkorlátot jelentette a földgömb datálásánál, ROMÁNIA, SZERBIA, BULGÁRIA elnyerte önállóságát (utóbbi kettố még határrajzzal sincs ábrázolva)! Ugyanígy hiányzik a már korábban is független
MONTENEGRÓ legalább határszintú jelölése.

„Rokona” a késóbbi, 1803-1905-ös kiadású földgömbnek (VGM ID 107).

A glóbusz átfedôsávval bôvített $30^{\circ}$-os, papírra nyomtatott gömbszegmensek hordozógömbre kasírozásával készült, 12 db - sarkokig nyúló - gömbszegmensbôl áll, pólussapkákkal. A hordozógömb, két félgömbbé préselt kartonrészből van összeillesztve, csak az illesztéseknél van gipszelve. Ezt követôen, szintén cikkelyekből készítettek vékony papírból egy alákasírozást. Erre került végül a földgömbtérkép-nyomat.

Teljes (III.) felszerelésú. Vörösbarnára pácolt, háromlábú esztergált faállványra illesztett két negyedkör alakú rézkar tartja a horizontkört, de a más kiadásoknál rendszerint megtalálható, az állványlábak között sárgaréz merevítőkkel kifeszített szelencében elhelyezett iránytû - amely a glóbusz pontos tájolását teszi lehetôvé -, itt hiányzik. A naptárkereten három (fekete, világoskék és sárga) színnel nyomott körgyúrû́n az egyfokos fokbeosztás, az év 365 napos beosztása, a hónapok neve, égtájak, évszakok találhatók [német nyelven (!)].

A sárgarézból készült teljes meridiángyúrúbe rögzített tengely körül forgatható a glóbusz, amelynek a vízszintessel (illetve a naptárkerettel vagy horizontkörrel) bezárt szöge a meridiángyúrú $1^{\circ}$-os beosztása segítségével pontosan beállítható. Óraköre nincs. Magassága: $65 \mathrm{~cm}$. (A horizontkör/naptárkeret magassága: kb. $43 \mathrm{~cm}$.)

\section{A glóbusz térképi tartalmának jellemzôi}

- A vetület: valószínúsíthetôen meridiánokban és Egyenlítôben hossztartó hengervetület („négyzetes hengervetület") transzverzális elhelyezésú változata a $30^{\circ}$-os gömbszegmensek elkészítéséhez.

- Ferrói kezdốmeridián.

- A szélességi és hosszúsági irányokban egyaránt $10^{\circ}$-os beosztású, sarkokig terjedô fokhálózat $12 \mathrm{db}$ $30^{\circ}$-os gömbszegmensre osztott. A kezdômeridián és az Egyenlítô $1^{\circ}$-os „létrás” ábrázolással kiemelt az egyébként folyamatos vonallal megrajzolt $10^{\circ}$-os fokhálózatból 
A térítôk és a sarkkörök szaggatott vonallal ábrázoltak. Az Ekliptika ugyancsak „létrás” ábrázolással kiemelt.

- A kontinensek és a jelentôsebb szigetek partvonalán túl a vízrajz a nagyobb folyókat és ezek fóbb mellékfolyóit, valamint (mélységábrázolás nélkül) a legjelentôsebb tavakat tartalmazza.

- A szárazföldi területek okker színezésúek, országhatárbanddal. Fekete színú lejtôcsíkozásos domborzatrajzzal egészül ki a szárazföld-ábrázolás.

- A településábrázolás nem kategorizált, a településjelek üres fekete körök. A fôvárosok és a legjelentôsebb települések szerepelnek csupán.

- A tengerek mélységábrázolás nélküliek (mélységpontértékek sincsenek). Alapszínük világoskék.

- A tengeráramlások sávjait fekete színú vonalkötegek mutatják, általában névvel megírtak (A Csendes tenger északi folyása, Egyenlítôi déli folyás, Az átlánti 's (!) Indiai tenger összefolyás, Sarkvidéki folyás stb.). Az összes tengeráramlás folyás megírással szerepel, áramlatmegírás nem található.

- A teljes névrajz magyaros írást követ. A Felkl-gömbökre jellemzó az ékezetes betúk gyakran pontatlan kezelése, ez itt nem jellemzó.

- A vízrajzi nevek a ma alkalmazott jobbra dőlő kurzív írással szemben balra dôlnek: az óceánok még tengerként megírva (NAGY TENGER vagy (az északi féltekén és külön megírva a déli féltekén) CSENDES TENGER, INDIAI TENGER, ATLANTI TENGER), tengerek (FÖLDKÖZI TENGER; Fekete tenger; Veres (!) tenger. Az összes tengeráramlás folyás megírással (Indiai tenger összefolyás, Sarkvidéki folyás, stb.). , tengeröblök (Mexikói öb.; HUDSON ÖB.), tengerszorosok (Davis szor, Bass szor), vízfolyások (Mississippi (!); Misszuri) és a tavak (Arál (!) tó., Njassi (!) tó) nevei. Jellegzetes, hogy sem a tengerek, öblök sem a szorosok nincsenek kötôjellel írva.

- Hasonlóan magyaros a szigetcsoportnevek (Havaji sz. es Sandvich szig.; Azori sz ${ }^{k}$; Deli
Shetland $s z^{\mathrm{k}}$; Amirante $S z^{\mathrm{k}}$ ) és a szigetnevek (Kiling sz, Bermuda sz), valamint a földfokok neveinek (Breton f., Északi f.) írásmódja.

- A kontinensek nincsenek megírva. A szárazföldi névrajz elemei között megtaláljuk az országneveket (EGYESÜLT ÁLLAMOK, BRIT AMERIKA, CANADA; FRANCZIA ORSZ.; SPANIOL (!); NÉMET ORSZ.; OROSZ BIRODALOM, SKOTHON, IRHON, SVEDHON); a településneveket (Stokholm, Madrid, Paris, Konstanczinápoly (!)); nagytájneveket (SZAHARA, SZUDAN, SZIBERIA, Gobi-sivatag sin Samo, ELÓ INDIA, TÜBET).

- A glóbusz Kelet-Közép-Európát ábrázoló részén szerepel helytelenül AUSZTRIA verzál megírása mellett Magyarorsz[ág] kurrens írásmódja, hiszen így a tartományokat jelölték. Ettôl délkeletre TÖRÖK ORSZ neve. A Kárpát-térség és szúk környezete területén még az alábbi neveket vélhetjük felfedezni: Bécs, Zágráb, Buda, Pest, Temesvár, Adriai tenger, Duna. Érdekesek a „KÖZÉP AMERIKA” (mint nagytáj) és az „AUSZTRALIA” (mint az egyetlen megnevezett „kontinens”. Nem nagybetûsek a „Rak téritô”, „Bak téritö”, „Északi sarkkor” és a „DéliSarkkör" megírások. Az Északi- és Déli-sarkok nincsenek megírva.

- A nyomtatáshoz felhasznált színek száma nyolc: fekete, világoskék, okker, élénksárga, sötétbarna, élénkvörös, téglavörös, zöld.

- Fekete: a teljes névrajz, vízrajz (vízfolyások, tókontúrok), a tengeráramlásrajz, a partvonalak, az Ekliptika, az egyenlító és a fokhálózat, valamint a lejtôcsíkozás

- Világoskék: a tengerfelületek, tavak.

- Okker: a szárazföldek felületi színezése.

- Élénksárga: az országhatárrajz egy része

- Sötétbarna: a domborzatábrázolás.

- Élénkvörös: az országhatárrajz egy része.

- Téglavörös: az országhatárrajz egy része.

- Zöld: az országhatárrajz egy része.
A sziget- és szigetcsoportnevek színes aláhúzása a (gyarmati) hovatartozást jelöli.

\section{Aukciókon, hirdetésekben felbukkant eddig ismeretlen Gönczy magyarította glóbuszok}

A továbbiakban olyan Gönczy magyarí totta glóbuszokat tárgyalnak a szerzók, amelyeknek hollétérôl nincs tudomásunk, azonban a róluk rendelkezésre álló fényképek alapján egyértelmúen kijelenthetố, hogy korábban nem ismert földgömbökrôl van szó. Így egyegy szerzó (esetünkben Gönczy Pál) életmúvének teljesebb bemutatásához, egy-egy kiadó (esetünkben a prágai Felkl cég) tevékenységének részletesebb megismeréséhez nyújtanak segítséget a glóbuszleírások és elemzések közzététele, ugyanakkor segítséget nyújthatnak egy elkészítendô magyar glóbuszkataszter összeállításához is.

\section{Az elsố (!) Gönczy- féle Felkl-magyarítás Prágábó1, 1870-bó1}

A glóbusz tartalmi elemzésénél csak az aukciós hirdetésben közölt, nem túl jó felbontású fényképfelvételekre támaszkodhatunk (7. ábra). Illetve, - mint majd látjuk - kereshetünk párhuzamokat a Virtuális Glóbuszok Múzeumában bemutatott egyik gömbbel, amelynek azonosítója: VGM ID 86.

A hirdetési leírás szerint:

„Jan Felkl, Prága 8,5” kb. 1870

Felkl korai asztali földgömbje magyar nyelven, az egyszerú felszerelés szerint ez a modell diákgömb. Jan Felkl a 19. század végének egyik legsikeresebb földgömbkészitöje volt. 1873ig évente 15000 földgömböt gyártott 10 különbözó nyelven Európa iskolái számára. A földgömbök azonban meglehetốsen ritkák. Nem tartják megörzésre érdemesnek, ha a földgömbök elavultak. Történeti szempontból jelentôs, mert ez a földgömb az egyik ritka Jan Felkl-modell, amely minden bizonnyal korábbi, minthogy Jan fiai a céghez csatlakoztak - 1870ben a cég neve J. Felkl E Son lett, és áttelepitették Roztokba. 
12 papírszegmensból áll, amelyet kézzel vittek fel egy gipszgömbre, egyszerü kasírozással (felragasztással), és fekete lakkozású oszlop tartja esztergált gyümölcsfatalppal. Kb. 18" magas, 8,5" átmérôjú.

A földgömb jó állapotban van, figyelembe véve az iskolai földgömbök használatának jellegét. Kopás és korból adódó fakulás (szinvesztés), a tartó állvány professzionális helyreállítása. Az Egyenlitőnél 1 hüvelykes hajszálrepedés látható Ausztrália északkeleti részén.

Ára: 995 \$”

Sem Plihál (2016), sem Novotná (2017) nem említ ilyen átmérôjû Felkl-gömböket, csak 8 incheseket. Valószínú, hogy az aukciós leírás felfelé, az említett szerzők pedig lefelé kerekítenek!
A lehetséges párhuzamokat is figyelembe véve, minden valószínúség szerint tehát:

$21,7 \mathrm{~cm}\left(8^{1 / 4}\right.$ bécsi hüvelyk) átmérójú, 1 : 58733000 méretarányú domborzati-politikai földgömb. Egyenlitối kerülete: $68,23 \mathrm{~cm}$.

Kontinenshatárbandos, lejtốcsíkozásos domborzatrajzú, a nagy folyóvölgyeket zöld színezéssel, a szárazföldeket part menti sû́rú vízszintes vonalkázással kiemelô domborzatipolitikai földgömb, országhatárokkal, országnevekkel, valamint párhuzamos vonalfonatokkal jelölt tengeráramlásábrázolással. Ferrói kezdômeridián, a földrajzi hosszúság $0^{\circ}$-tól $360^{\circ}$-ig történô számozása és fordított állásban megrajzolt Ekliptika jellemzi. A földgömb kolofonja, hasonlóan a többi Gönczy által magyarított glóbuszéhoz ${ }^{1}$ : A | FÖLD | a legújabb felfedezések nyomán | Magvarul (!) szerkesztette | Gönczy Pál | a m. kir. közoktatási | minister megrendeléseböl (!). | Kiadta | Felkl János | PRÁGÁBAN.

Ha kiadásának idejét szeretnénk meghatározni, segítségünkre lehet, hogy egy korábbi Felkl-glóbusz „rokona” (VGM ID 86). A „rokonság” alapja a névrajz, mivel névrajzát tekintve a $21,7 \mathrm{~cm}$ átmérôjú, 1867-1870 közé (Márton 2010b), illetve 1861-1867 közé (Plihál 2016) datált, Prágában Felkl Ján által kiadott, Pesten Lauffer és Stolp bizománya által forgalmazott földgömbhöz áll legközelebb (8. ábra). Azt azonban a kolofon szerint „Magyarul szerkeszté Hunfalvy János." (9. ábra).

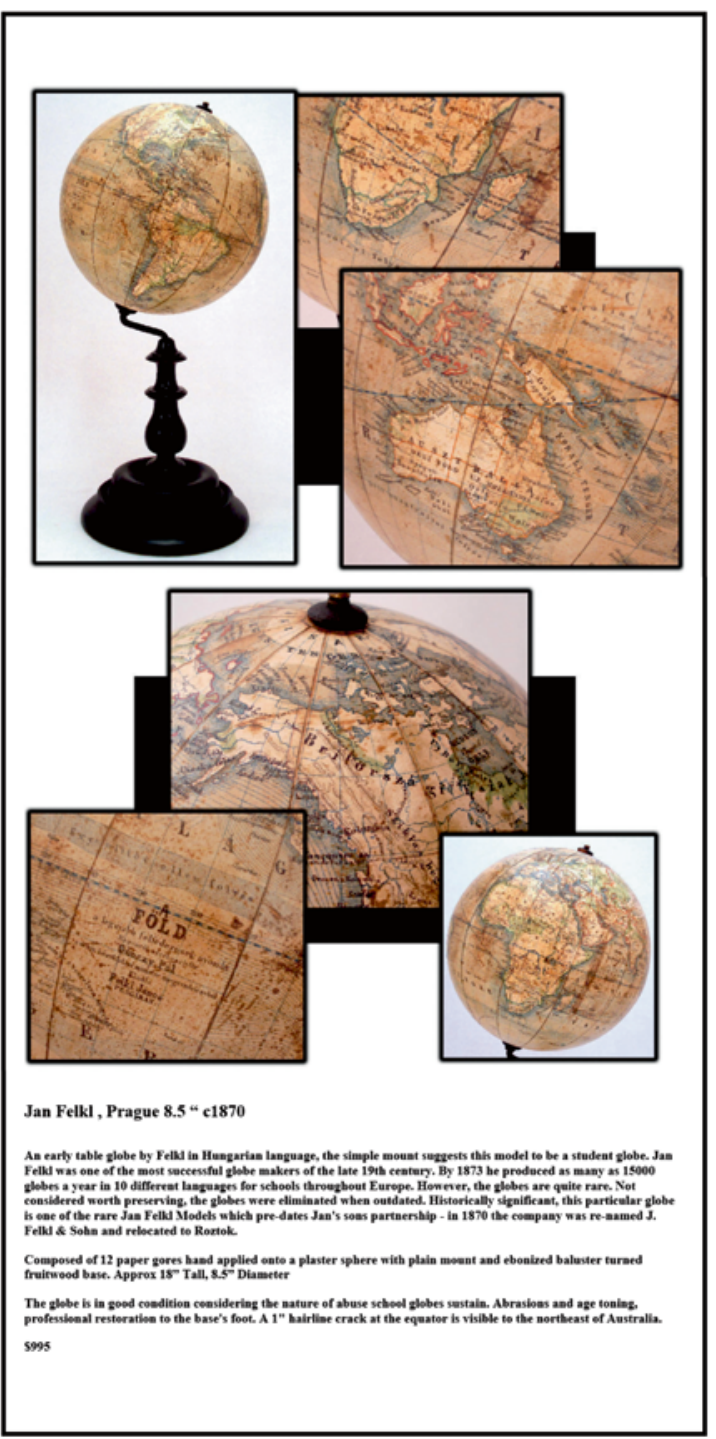

7. ábra. A Felkl-Gönczy-glóbusz aukciós hirdetése (Császi Tamás szivességébốl)

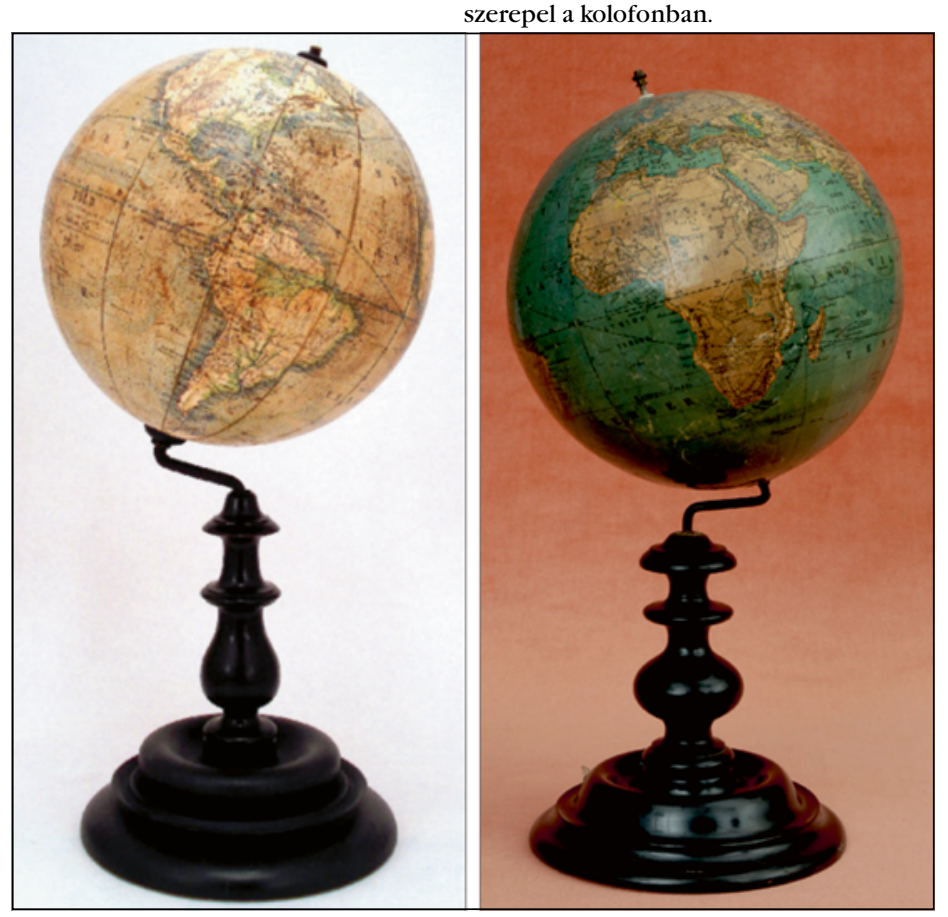

8. ábra. A Felkl-Gönczy-(balra) és a Felkl-Hunfalvy-glóbusz (jobbra) (Fotó: Nemes Zoltán)

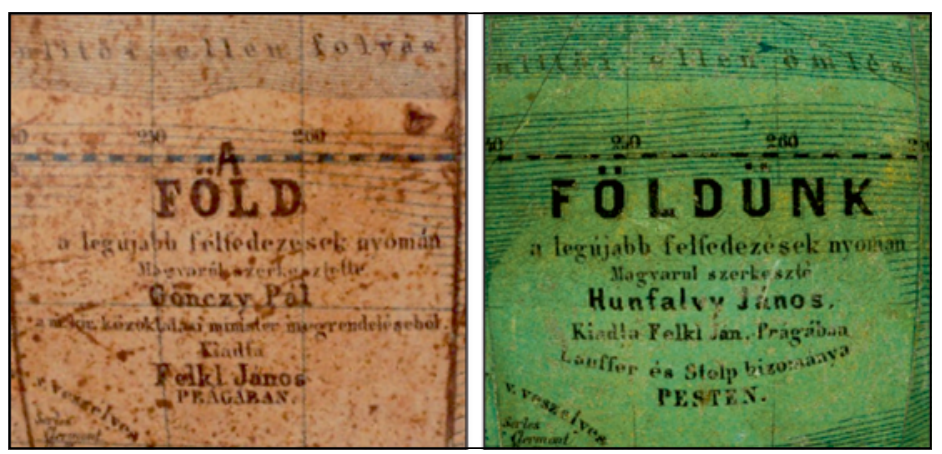

9. ábra. A közel egykorú Felkl-Gönczy-és Felkl-Hunfalvy-glóbusz kolofonja 


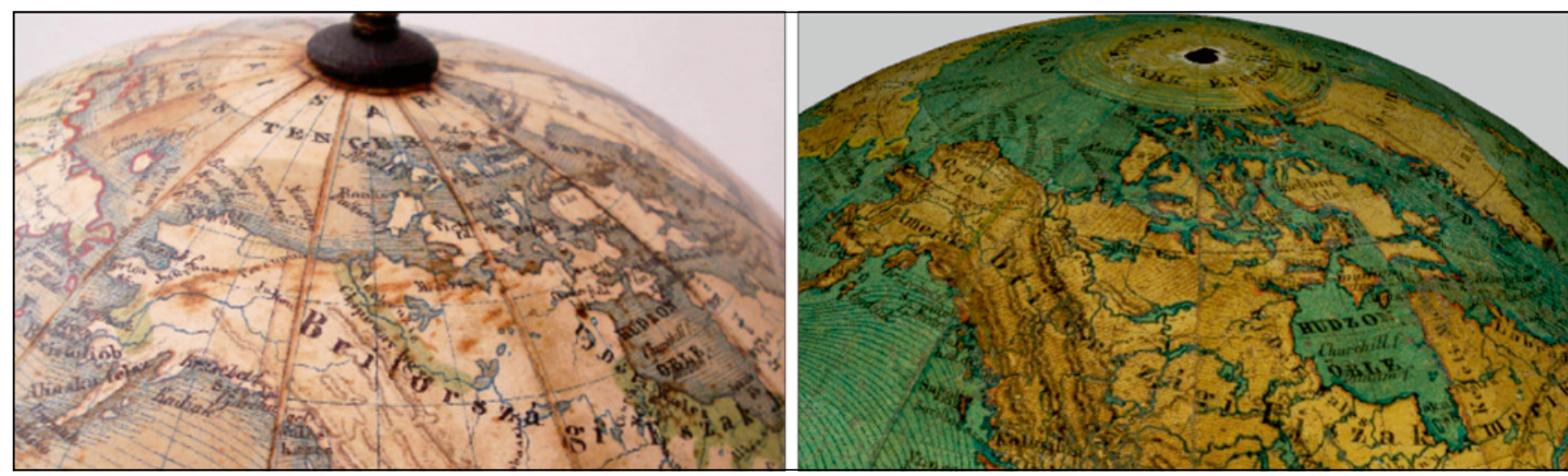

10. ábra. A Felkl-Gönczy-és a Felkl-Hunfalvy-glóbusz észak-amerikai része

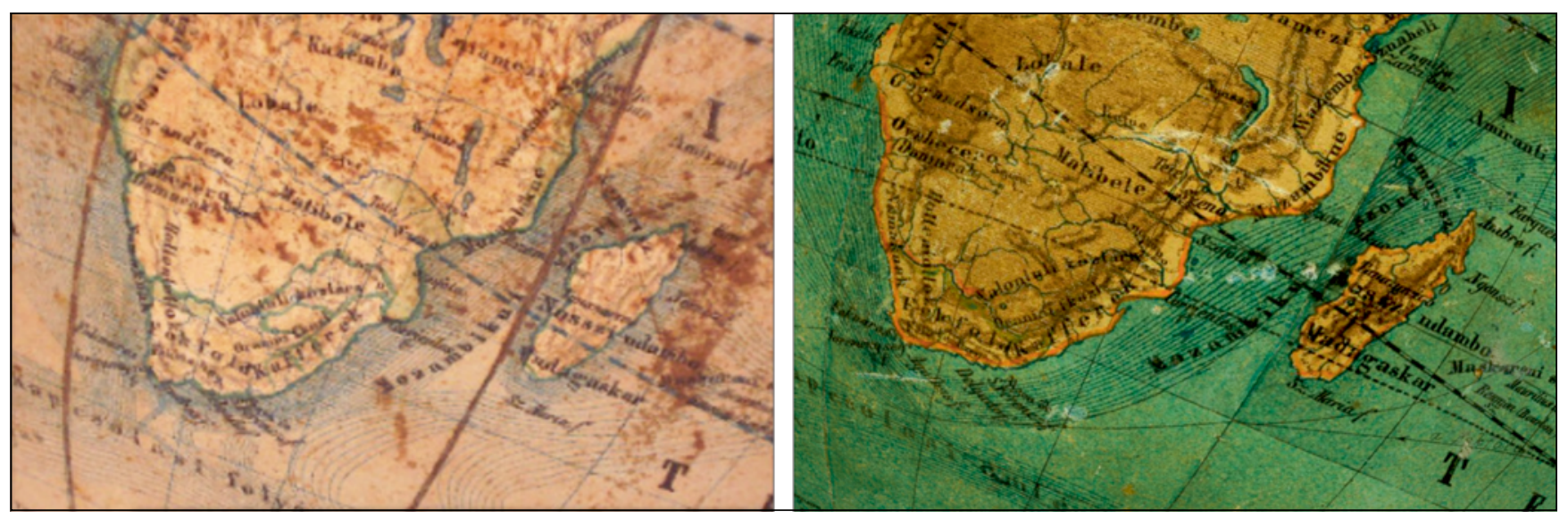

11. ábra. A Felkl-Gönczy-és a Felkl-Hunfalvy-glóbusz dél-afrikai része

Mai tudásunk szerint a Hunfalvygömb kiadásának idejét 1868-ra vagy az utánra kell tennünk. Ugyan Orosz Amerika (Alaszka) (amelyet az Egyesült Államok 1867-ben vásárolt meg Oroszországtól, és a szerzôdést az amerikai elnök június 20-án alá is írta) megírása, határrajza és bandja még szerepel a gömbön, Magyarország megírása azonban már a kiegyezés utáni kiadásra utal. Ha viszont az utóbbit elfogadjuk - mivel a király által jóváhagyott anyag csak 1867. december 29-én került a magyar képviselôház elé - így az a glóbuszon legkorábban csak az 1868-as kiadásnál jelenhetett meg. Ugyanakkor Gönczynél - a most tárgyalt gömbön Orosz Amerika megírása már egyértelmúen hiányzik (10. ábra).

Mivel Európát nincs módunk részletesen tanulmányozni Gönczynél (lásd 7. ábra), akár 1867-re is datálhatnánk ezt a glóbuszt, mint legkorábbi kiadási idôpontra. Szerencsére azonban bizonyosak lehetünk az 1870. kiadási év felôl. A Gönczy múveit soroló Szinyei (1894) vagy az Akadémiai Almanach 1892. évi kötete jegyzékéból - témánkhoz kapcsolódóan - egyetlen tételt emelünk ki: „23. Földgömb magyar nyelven. Kiadja Felkl, Prágában. 1870."

Glóbusztörténeti szempontból érdemes itt megjegyezni az összehasonlítás alapjául szolgáló Hunfalvyglóbusz kapcsán, hogy a Márton (2010a, 2010b, 2011), Plihál (2016) vagy Novotná (2017) által meghatározott kiadási évszámok csak a földgömbtérképek tartalma alapján becsült dátumok, $s$ a most a vizsgálódásba bevont Fodor-mú (2006) még csak meg sem említi azt, hogy Gönczyvel egy időben Hunfalvy is készített földgömbmagyarításokat Felklnél. A két neves tudós együttmúködésére csak indirekt módon - például az itt tárgyalt földgömbök csaknem tökéletes névrajzi egyezéséból - következtethetünk. Késôbbi közös munka említésére már találunk példát: „39. Schneider természetrajzi képes átlásza, fordították Hunfalvy János és Gönczy Pál 1881" (Szinyei 1894), s ez még Fodornál (2006) és másoknál is említésre kerül. E kérdéskör tisztázására is fontos lenne kutatásokat végezni!
A Gönczy-glóbusz átfedôsávval bôvített $30^{\circ}$-os, papírra nyomtatott gömbszegmensek hordozógömbre kasírozásával készült, 12 db - sarkokig nyúló - gömbszegmensból áll, pólussapkák nélkül. A hordozógömb feltehetôen préselt papírmasé, amelynek egyenetlenségeit gipszbevonattal simították.

Egyszerû, ún. I. számú felszerelésû asztali, oktatási földgömb. Feketére lakkozott esztergált korongra helyezett, ugyancsak esztergált oszlop alkotja a faállványt, amelybe illesztett, a vízszintessel 66,5 fokot bezáróan meghajlított fémhuzaltengely körül forgatható a gömb. Óraköre nincs. Magassága: $43,0 \mathrm{~cm}$.

A dél-afrikai rész tüzetes vizsgálata azt mutatja, hogy a vízrajz (pl. tavak), a partvonalak rajzolata Gönczynél elnagyoltabb (11. ábra).

\section{A glóbusz térképi \\ tartalmának jellemzói}

- A vetület: valószínúsíthetôen meridiánokban és Egyenlítőben hossztartó hengervetület („négyzetes hengervetület") transzverzális elhelyezésú változata a $30^{\circ}$-os szélességú pólustól 
pólusig tartó gömbszegmensek elkészítéséhez.

- Ferrói kezdômeridián. A hosszúság számozása 0-tól $360^{\circ}$-ig történik.

- A szélességi és hosszúsági irányokban egyaránt $10^{\circ}$-os beosztású, sarkokig terjedô fokhálózat $12 \mathrm{db}$ $30^{\circ}$-os gömbszegmensre osztott. A kezdômeridián és az Egyenlítô $1^{\circ}$-os „létrás” ábrázolással kiemelt az egyébként folyamatos vonallal megrajzolt $10^{\circ}$-os fokhálózatból. A térítôk és a sarkkörök szaggatott vonallal ábrázoltak. Az Ekliptikát ugyancsak „létrás” ábrázolással kiemelten rajzolták meg.

- A kontinensek és a jelentôsebb szigetek partvonalán túl a vízrajz a nagyobb folyókat és ezek fôbb mellékfolyóit, valamint a legjelentôsebb tavakat tartalmazza.

- A szárazföldek alapszíne fehér. A partvonalrajzot a tenger felóli oldalán sûrû, vízszintes, sötétkék sraffozás, a szárazföldi oldalon keskeny kontinenshatárband kíséri. A legnagyobb folyóvölgyek tengerközeli völgyszakaszait (síkságok) zöld színezéssel ábrázolták, míg a nagy magasságokat elérō hegységeket, illetve a legmeredekebb terepszakaszokat mutató területeket barna színú lejtốcsíkozásos domborzatrajzzal emelték ki. - Az országhatárok amennyire kivehetố - pont-vonalpont stílusú szaggatott vonallal ábrázoltak. Ezeket eltérô színezésú, az országok területén elhelyezkedô határbandok kísérik.

- A tengerek mélységábrázolás nélküliek, alapszínük fehér. Sötétkék színú, íves, sứrú vonalfonatokkal ábrázolták a tengeráramlásokat. A tengeri hajójáratok útvonala nem szerepel. - A Gönczy-féle névrajz csak korrektúraszintű eltéréseket mutat Hunfalvyhoz viszonyítva; a nevek szinte $100 \%$-ban megegyeznek mind írásmódjukat, mind elhelyezésüket tekintve, de nem azonos nyomólemezrôl származnak! Úgy tû́nik, hogy Gönczy alapjaiban elfogadta Hunfalvy földrajzi neveit. A névrajzi súrúség is gyakorlatilag azonos. Mindkettônél szerepel az ETHIOP TENGER (a Guineai-öböltôl D-re), de a KLARIS TENGER helyén Gönczynél már KORALL TENGER áll. Az óceán megírás helyett itt még mindketten (!) világtengert használnak, de a (tenger)áramlás helyett Hunfalvynál ömlés, Gönczynél folyás szerepel, és Gönczynél nincsenek áramlásirányt mutató nyílfejek.

- Egyébként a teljes névrajz magyaros írást követ, illetve erre törekvô, a litográfus azonban vélhetốen nem magyar anyanyelvú. Erre az ékezetes betűk gyakran pontatlan kezeléséből és a nyelvi hibákból következtethetünk (Magvarul, megrendeléseböl, Fokfold, Kiralyne Földe). A vízrajzi nevek a ma alkalmazott, jobbra dőlő, kurzív írással szemben balra dőlnek: óceánok (ATLANTI, CSENDES és IND VILÁG TENGER = Indiaióceán), tengerek ([ÉSZAKI] JEGES TENGER, DELSINAI TENGER, Banda teng., Harafura tenger), tengeröblök (Deli öböl = Nagy-Ausztráliai-öböl, Karpen tariai oböl (!), HUDZON ÖBLE), tengerszorosok (Torres szor; Mozambikui szor), tengeráramlások (Egyenlitôi ellen folyás; Déli ausztraliai folyás, [Delatlanti] kapcsolasi folyas), vízfolyások (Jukon [rossz helyen]) és a tavak (Nyassza) nevei. Hasonlóan magyaros a szigetcsoportnevek (Szunda Szigetek, Karolina szig, Salamon sz, Komori sz. = Comore-szigetek) és a szigetnevek (Vancouver sz, Madagaskar, Van Diemen folde Taszmania, Uj Guinea), valamint a földfokok neveinek (Joremenyseg f.) írásmódja. A kontinensek nincsenek megírva. A szárazföldi névrajz elemei között megtaláljuk az országneveket (Britországi Észak Amerika = Kanada, Brazilia); országrészneveket (Nyugati Ausztralia, Deli Ausztralia, Uj Deli Wales, Viktoria, Kiralyne Földe = Queensland); a településneveket (Fokváros, Szena [a Zambézi partján]); a népneveket (Hottentottok, Kafferek, Papuak); a jelentôsebb hegységek nevét (Sziklas hegyseg), a (nagy)táj- (terület-) neveket (KÖZÉP AMERIKA, Fokfold, Van Diemen folde [ÉNy-Ausztráliában], Karpentaria). Szerepel az ÉSZAKI SARK megírás is.

- A nyomtatáshoz felhasznált színek száma négy: fekete, sötétkék, barna és zöld.
- Fekete: a teljes névrajz.

- Sötétkék: a partvonal, vízrajz (vízfolyások, tókontúrok), a fokhálózat (a kiemelt kezdőmeridiánnal és Egyenlítôvel), az Ekliptika, a tengerpartokat kísérô sûrú vízszintes sraffozású sáv, a tengeráramlások rajza, az országhatárok és a településjelek.

- Barna: a csíkozásos domborzatrajz.

- Zöld: a jelentôsebb folyóvölgyek (síkságok).

\section{Korábban ismeretlen 21,7 cm-es Felk1-Gönczy- glóbusz a "Jófogás” hirdetésében}

Az itt tárgyalt glóbusz bemutatásánál csak a hirdetésben megjelent igen gyenge minôségú fényképfelvételekre támaszkodhatunk. A glóbusz eredeti állványa megsemmisült. Úgy tûnik azonban, hogy meridiánköre épen megmaradt (12. ábra).

$21,7 \mathrm{~cm}\left(8_{1 / 4}^{1 / 4}\right.$ bécsi hüvelyk) átmérójû́, 1 : 58733000 méretarányú politikai- domborzati földgömb. Egyenlítôi kerülete: $68,23 \mathrm{~cm}$.

A rendelkezésre álló fényképfelvételek alapján valószínúsíthetôen kontinenshatárbandos, lejtôcsíkozásos domborzatrajzú, a nagy folyóvölgyeket zöld színezéssel, a szárazföldeket part menti súrú vízszintes vonalkázással kiemelő domborzatipolitikai földgömb, országhatárokkal, országnevekkel, valamint párhuzamos vonalfonatokkal jelölt tengeráramlásábrázolással. Ferrói kezdőmeridián, a földrajzi hosszúság $0^{\circ}$-tól $360^{\circ}$-ig történô számozása, és fordított állásban megrajzolt Ekliptika jellemzi. A kolofon: „A | FÖLD | a legüjabb (!) felfedezések nyomán | Magvarúl (!) szerkesztette | Gönczy Pál | a m. kir. közoktatási minister megrendeléseböl (!). | Kiadtak (!) | Felkl J. és fia | Rozstokon, Praga m Mett. (!)"

A kolofon alapján bizonyosan állítható, hogy ezzel a kiadással a korábbiakban nem találkoztunk! Ugyanakkor felvetődik az a kérdés is, tekintettel a magyar szövegben elkövetett számos betűtévesztésre, amelyek közül a leginkább zavaróakat [a késóbbi kiadásoknál (?!)] kijavították, vajon nem ez 

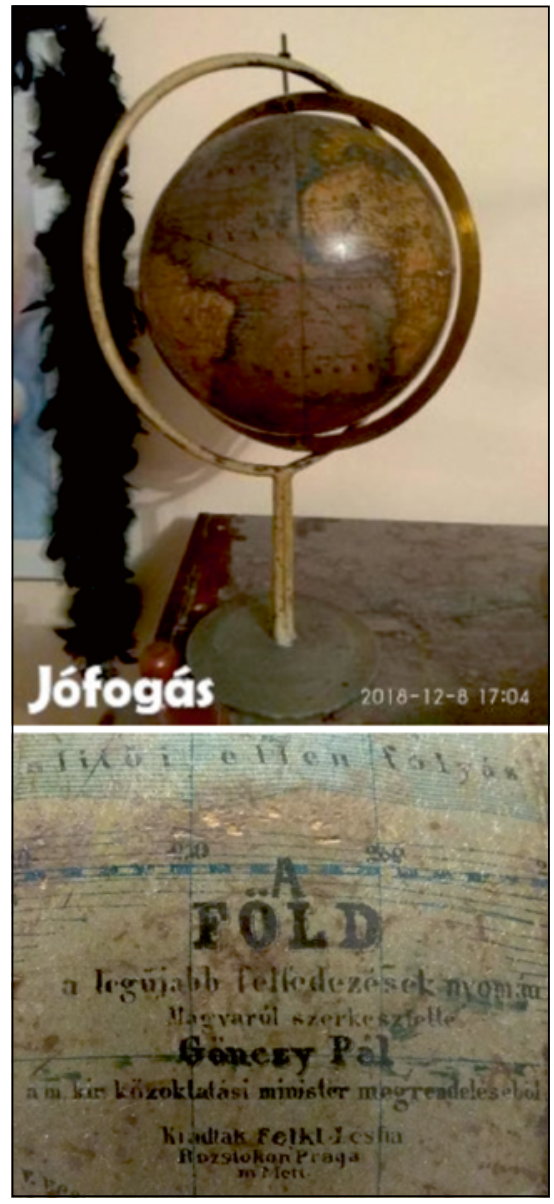

12. ábra. A „Jófogás" hirdetésén megjelent 21,7 cm-es glóbusz. (Toronyi Bence gömbfotó-gyújtése)

a példány volt-e az elsô kiadás egyik példánya? Sajnos a glóbusz megsemmisült, így tanulmányozására nincs mód. Mindenesetre a pontosan el nem olvasható, de „kitalálható” ETHIOP TENGER vagy az ATLANTI VILÁG TENGER megírás alapján a korai Gönczy-gömbök közé sorolhatjuk.

\section{1,6 cm-es Felk1- \\ Gönczy-földgömb a \\ Nagyházi-aukción}

$31,6 \mathrm{~cm}$ (12 bécsi hüvelyk) átmérójú, 1 : 40379000 méretarányú domborzati-politikai földgömb. Egyenlítối kerülete: 99,25 cm.

Hipszometrikus színezésú, lejtôcsíkozásos domborzatrajzú, országhatárbandos, 1897-ben kiadott glóbusz, párhuzamos vonalfonatokkal jelölt tengeráramlásokkal, áramlásnevekkel és nyilakkal jelölt áramlásirányokkal, tengermélység-adatokkal, hajózási útvonalakkal. Greenwichi kezdőmeridián, valamint helyes állásban megrajzolt Ekliptika jellemzi. A kolofon: „A FÖLD | magyarul szerkesztette GÖNCZY PÁL a m kir közoktatásügyí (!) | minister megrendeléséböl (!) | kiadta | FELKL J. ÉS FIA | RozToK Prága mellett | Második javított kiadás. 1897. | Átvizsgálta Berez (!) Antal."

A kolofon eltérései a korábban is ismert „Második javított kiadás”októl (pl. a hibásan írt Berez (!) név) [13. a) ábra], de még inkább a jó állásban megrajzolt Ekliptika és a greenwichi kezdômeridián [13. b) ábra] jelzik, hogy valóban javított és korábban ismeretlen kiadásról van szó.

Egyszerú, ún. I. számú felszerelésú asztali, oktatási földgömb. Feketére lakkozott esztergált korongra helyezett, ugyancsak esztergált oszlop alkotja a faállványt, amelybe illesztett, a vízszintessel 66,5 fokot bezáróan meghajlított fémhuzaltengely körül forgatható a gömb [13. c) ábra]. Óraköre nincs. Magassága $50 \mathrm{~cm}$.

\section{1,6 cm-es Felk1- Gönczy-glóbusz a Honterus-aukción}

Itt érdemes felhívni a figyelmet arra, hogy „a magyar királyi közoktatásügyi miniszter megrendelésébôl” a Felkl, illetve a Felkl és fia által kiadott Gönczy magyarította földgömbök anyagi állami támogatása 1895-ig állt fenn (Plihál 2016, Márton-Toronyi 2020). Meglepó módon azonban a kolofonjukban 1896-ot vagy 1897-et feltüntető, 31,6 cm átmérôjû, eddig megismert gömbök még hivatkoznak a miniszter megrendelésére (pl. a fentebb bemutatott vagy a VGM ID 100 azonosítójú glóbuszok). Sốt! 1907-ig jelentek meg más átmérôjúek is, ezzel a hivatkozással. Valószínú, hogy üzleti fogásról van szó, a támogatás hiányában is ,jól mutatott" a felirat, mintegy ajánlásul szolgált a vásárlók felé, hiszen nemcsak az iskolák, de polgárok is megvásárolhatták. 1896 után pedig már megjelent a magyar konkurencia is Kogutowicz Manó földgömbjei alakjában!

Ismereteink szerint az itt tárgyalt glóbusz az elsố, amelyik nem hivatkozik a miniszter megrendelésére. 1909-et írunk, s nyilvánvaló nyomós oka lehetett ennek az is, hogy a Felkl és fia által kiadott földgömböket 1908ban iskolai használatra alkalmatlannak minôsítették!

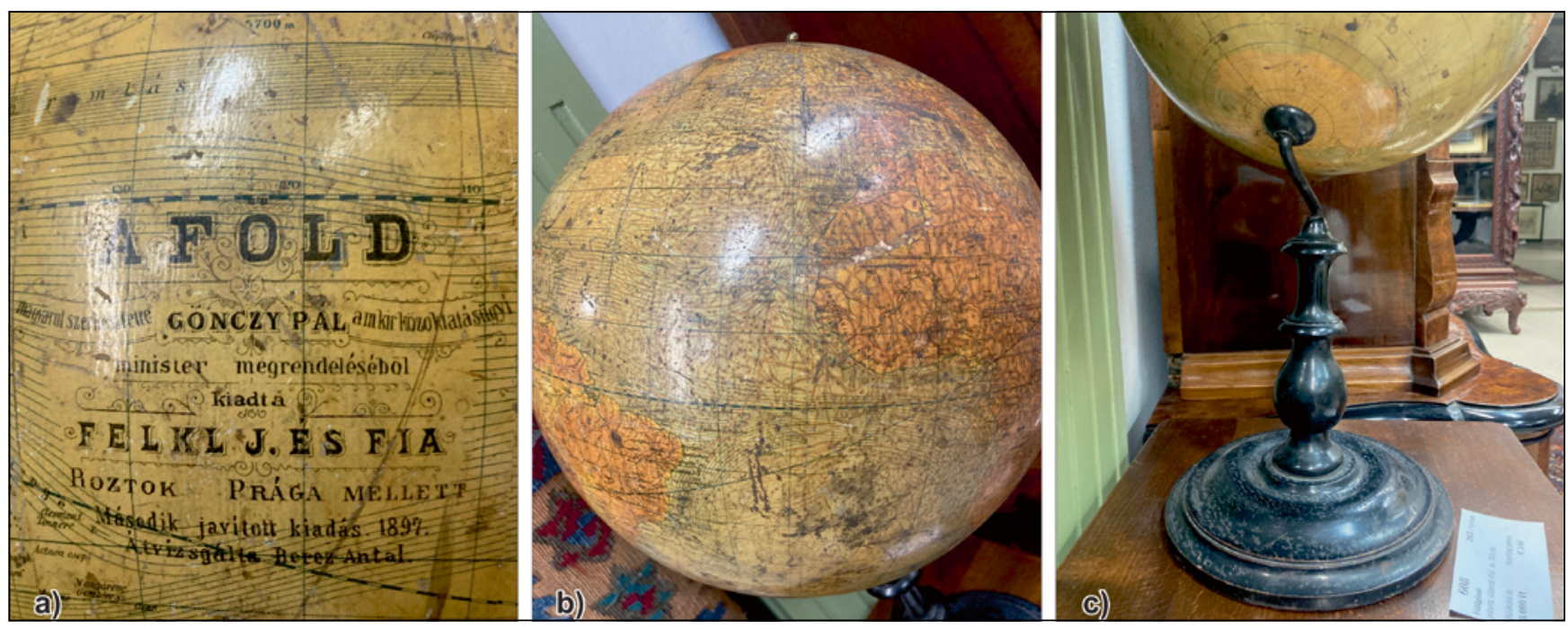

13. ábra. A Nagyházi-aukción megjelent 31,6 cm átmérôjü glóbusz: a) a kolofon; b) a földgömb; c) az állvány. (Toronyi Bence gömbfotó-gyüjtése) 
Ami a glóbuszról elmondható:

$31,6 \mathrm{~cm}$ (12 bécsi hüvelyk) átmérójiú, 1 : 40379000 méretarányú domborzati-politikai földgömb. Egyenlítối kerülete: 99,25 cm.

Hipszometrikus színezésú, lejtôcsíkozásos domborzatrajzú, országhatárbandos, 1909-ben kiadott glóbusz, párhuzamos vonalfonatokkal jelölt tengeráramlásokkal, áramlásnevekkel és nyilakkal jelölt áramlásirányokkal, tengermélység-adatokkal, hajózási útvonalakkal. Greenwichi kezdőmeridián, valamint helyes állásban megrajzolt Ekliptika jellemzi. A kolofon: „FÖLDGÖMB | magvarúl (!)
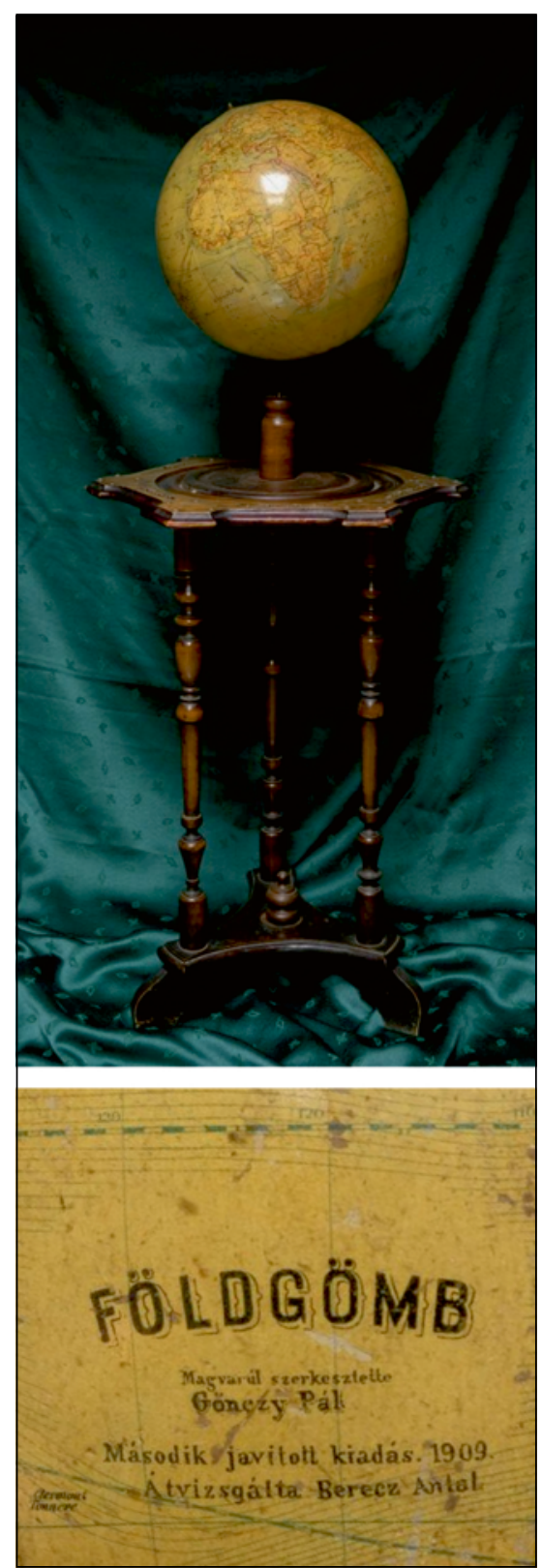

14. ábra. A Honterus-aukción megjelent $31,6 \mathrm{~cm}$ átmérôjiú glóbusz (Toronyi Bence gömbfotó-gyüjtése) szerkesztette | GÖNCZY PÁL | Második javitott (!) kiadás. 1909. I Átvizsgálta Berecz Antal".

Meglepó a kolofon szövegében a „FÖLDGÖMB” írásmódja, hiszen a korábbi glóbuszokon hosszú Ô-vel írva, „FÔLDGÖMB”-ként szerepel. Egyedi állványát bizonyára korábbi tulajdonosa készíttette.

\section{Csodálatos 47,4 cm-es Felkl-glóbusz a Honterus-aukción}

Nagyszerú állapotban fennmaradt eddig ismeretlen - földgömb került „kalapács alá” a Honterus-árverésen, amelynek szépségét csak fokozta Lente Zsuzsanna restaurátornak a glóbuszt valóban „újjáa-varázsoló, az évszázad elsô évtizedében végzett múvészi munkája.

Tulajdonképpen „közeli rokona” ugyan a Kalocsai Főszékesegyházi Könyvtárban, az Érseki Palotában (VGM ID 137), valamint az érdi Magyar Földrajzi Múzeumban őrzött példánynak (VGM ID 149), de a részletekben elmélyülve ismét csak egy példát találunk arra, hogy az azonos kolofonszöveg mögött más-más kiadás rejtôzik. Mivel jelenleg négy (a kolofonok szerint egykorú) ilyen földgömböt ismerünk, érdemes ezeket „párhuzamba állítani”, hogy néhány látványos különbséget bemutathassunk (15. ábra). A negyedik, eddig nem említett földgömb - sajnos az 1970es években elkövetett szakszerútlen „restaurálás" miatt - az elôző́ekhez képest nehezen értékelhetô példány az ELTE Térképtudományi és Geoinformatikai Intézetében található.

Röviden összefoglalva a glóbuszok tartalmi és formai jellegzetességeit, az alábbiakat mondhatjuk el.

Ami közös:

47,4 cm (18 bécsi hüvelyk) átmérójiú, 1 : 26919000 méretarányú domborzati-politikai földgömb. Egyenlitôi kerülete: $148,87 \mathrm{~cm}$.

A kolofon: „A | FÖLD | magyarul szerkesztette | Gönczy Pál | a m. kir. közoktatásügyi minister megrendeléséböl (!) | kiadta | FELKL JÁNOS | PRÁGÁBAN | -x- | Köre metszette és nyomatta (!) | H. KUNSCH. | LIPCSÉBEN."

Ferrói kezdőmeridián és innen kelet felé $360^{\circ}$-ig haladva $10^{\circ}$-onként megírt hosszúsági körök, valamint fordított állásban megrajzolt Ekliptika (!). Lejtốcsíkozásos domborzatábrázolás. Pontsorral és/vagy keskeny, színes határbanddal jelölt országhatárok. Magyar(os) névrajz. 1870-es vagy közvetlenül azt követô kiadás.

Ha kiadási sorrendet kell megállapítani, azt mondhatjuk, hogy az elsô minden bizonnyal a Kalocsai Fôszékesegyházi Könyvtárban ôrzött földgömb (VGM ID 137). E mellett szól az, hogy a Magyar Földrajzi Múzeum kiállításán szereplô glóbusz (VGM ID 149) restaurálásakor feltárt német nyelvú földgömbtérkép-nyomat (amely fölé a magyart kasírozták, tehát időben megelôzte annak elkészítését), a technológiai feldolgozás [színvilág, jelkulcs, rajzi megoldások, pl. a kék tengerben fehér (negatív) áramlásvonalak stb.] szempontjából ezzel egyező. Kontinenshatárbandos szárazföld-ábrázolás jellemzi (pl. Ázsia vörös, Afrika zöld).

A második a kiadási sorrendben a Honterus-aukciós glóbusz, amely az északi pólussapka tartalma és rajzolata alapján újabb (ÉNy-Grönland, Ferenc József-föld). Azonban az elôzóhöz hasonlóan még Grönland folytatásában az „Északi Jeges tengert” szinte teljesen átszelô, a Bering-szoros irányába elhúzódó szárazulatot mutat, amelynek végén a ma Vrangel-szigetként ismert területen (a Csukcs-föld ÉNy-i szélén a tengerbe nyúló Selagszkij-foktól kb. $10^{\circ}$-kal K-re) a következô megírást találjuk: „Magus hegys. terjedelmes szar az föld”. Magát Csukcs-földet a népnév: „Tsuktsok”, a földfokot pedig (németesen): „Schalagskii f.” jelöli. A technológiai feldolgozás [színvilág, jelkulcs, rajzi megoldások, pl. a kék tengerben fekete áramlásvonalak stb.] változott. A tengerábrázolás is új! A bizonytalan tenger-szárazföld átmenetet a szélességi körökkel párhuzamos, de ritkább vonalkázás jelöli. Jól megfigyelhetố ez éppen a Vrangel-sziget környéki tengerrészeken. Kontinenshatárbandos szárazföld-ábrázolás jellemzi (pl. Ázsia zöld, Afrika vörös).

A harmadik a Magyar Földrajzi Múzeumban kiállított glóbusz (VGM ID 149). Az időbeli besorolását a jeges-tengeri terület vizsgálata erôsíti. Az idézett névrajzi elemek nem 
változnak ugyan, de a „Magus hegys. terjedelmes szar az föld" megíráshoz kapcsolódva megjelenik a Vrangel-sziget partvonalrajza! [A szigetet Tomas Long, egy amerikai bálnavadászhajó kapitánya 1867-ben nevezte el Vrangelról. A mintegy $125 \mathrm{~km}$ széles Long-szoros pedig, amely a szigetet a kontinenstốl elválasztja, az ó nevét viseli (Magidovics 1961, p. 654.).]

A negyedik pedig - az ELTE Térképtudományi és Geoinformatikai Tanszékén, (ma már) Intézetében ôrzött példány - a Magyar Földrajzi
Múzeuméval egyezônek túnik, csupán horizontkörének/naptárkeretének rajzolata erôsen megkopott, óraköre helyén egy réz „díszgomb” található, illetve iránytứje hiányzik (az utóbbi tartószelencéje azért túlélte az idôk viharait).

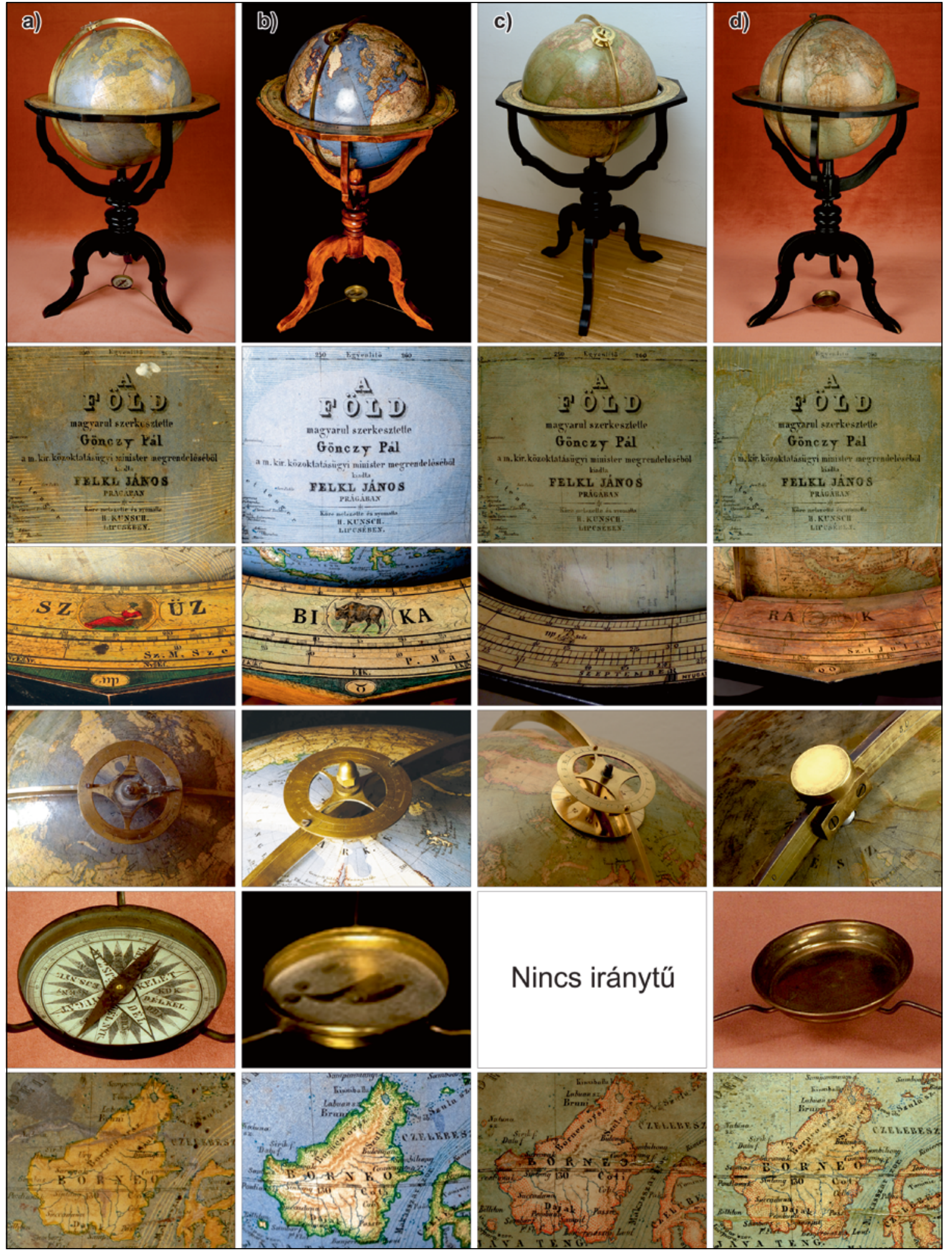

15. ábra. Az eddig megismert 47,4 cm átmérôjü Felkl-Gönzy-glóbuszok (1870 körül): a) Kalocsáról; b) a Honterus-aukcióról; c) Érdrốl; d) az ELTE-rôl. (Fotók: Fischerné Grócz Zita, Lente Zsuzsanna, Nemes Zoltán és Toronyi Bence gömbfotó-gyüjtése) 


\section{Összefoglalás és problémafelvetés}

A három cikkből álló sorozat alapján megállapítható, hogy Gönczy Pál földgömb-magyarosítása életmúvének fontos részét teszi ki, és rengeteg földtekén láthatjuk alkotó tevékenységét. A jelenleg ismert földgömbök és az elmúlt lapszámokban publikáltak alapján még messze nem beszélhetünk arról, hogy az életmúvének ezen szegmensét teljes körűen sikerült volna feltárni, elég utalnunk a már többször idézett Akadémiai Almanach Gönczy-bibliográfiájára, amelyben „Schotte sima és domború földgömbjei szerepel (MTA Alm. 1892, p. 137.). Egyetlen domború földgömbbel sem találkoztunk!

A Felkl cég által gyártott és Gönczy magyarította glóbuszok, mint azt bemutattuk, az 1870-1909 közötti időszakra tehetôk. Az 1870-es évek környéki gömbök esetén jelentôs névrajzi egyezésre mutattunk példát egy Hunfalvy által magyarított földgömbbel. Kettôjük közös tevékenysége további kutatást igényelne, melyet valószínúsíthetôen a később előkerülố glóbuszváltozatok is segíthetnek. A Felklgömbök esetén bemutattuk, hogy az azonos megírású kolofonokhoz különbözô tartalmú és korú glóbuszok tartozhatnak. Tanulmányunk alapján az a kép kezd kirajzolódni, hogy egy német vagy cseh nyelvú eredeti gömbnek több magyar verziója van, a folyamatos helyesírási és tartalmi javítások következményeként. Ismertetünk közel 20 darab Felkl által gyártott és Gönczy magyarította földtekét és ezek vagy igen közeli rokonai egymásnak vagy különböznek az azonos átmérôjúektôl. Ez alapján feltételezhetô, hogy egy késôbbiekben felállítandó magyar glóbuszkataszter ezen szegmense tartokülönféle átmérôkkel. Berlin, 1872." gat még kihívásokat és kutatni valót.

A Schotte cég által gyártott földgömbökbôl csak Gönczy magyarítást ismerünk, amelyek kiadásai az 18721909 közötti évekre tehetôk. Schottegömbökból jelentôsen kevesebbel találkozhatunk, amely részben abból is következhet, hogy ezen gyártmányok csak 1873-ig voltak támogatva a kormány által, míg a Felkl cég által gyártottak 1895-ig. A Schotte-földgömbök esetén a kolofon a helyesírási hibákat leszámítva, szinte megegyezik átmérôtől és időszaktól függetlenül. Jelenlegi ismereteink alapján itt a kiadások is jobban „korszakolhatók” a jelenleg ismert példányok alapján (lásd alábbi táblázat).

Az új kiadások okai az alábbiak lehettek: Az 1878 kiadás idejére teljes körúen megtörtént Afrika feltérképezése. Az 1884-1885. évi új kiadást indokolja az 1884. évi washingtoni Meridián konferencia, a greenwichi kezdômeridián bevezetése, a 1884-1885. évi berlini konferencia és a következményeként kötött szerzôdések. Azt, hogy 1885 és 1905 között voltak-e még újabb kiadások, jelenleg nem ismerjük, és az 1905ös kiadáshoz sem tudunk olyan jelentôs eseményt párosítani, mint amilyen a korábbi új kiadásokat szükségessé tette. A fentiek alapján látható, hogy megválaszolandó kérdés ebben az esetben is van még bôven.

\section{Köszönetnyilvánítás}

Ezúton mondunk köszönetet Korányi G. Tamás magángyújtőnek; a zalaegerszegi Göcseji Múzeum történészfőmuzeológusának, Megyeri Annának és fotósának, Bicskei Józsefnek; Császi Tamás magángyújtônek; a Kalocsai Fôszékesegyházi Könyvtár vezetôjének, Fischerné Grócz Zitának; valamint Lente Zsuzsanna restaurátornak önzetlen és pótolhatatlan segítségükért. Külön köszönet jár Nemes Zoltánnak, az ELTE Térképtudományi Intézet fotósának készséges közremúködéséért.

\begin{tabular}{|l|l|l|l|}
\hline kor \átmérô & $11,9 \mathrm{~cm}$ & $23,7 \mathrm{~cm}$ & $32,9 \mathrm{~cm}$ \\
\hline 1872 & $\begin{array}{l}\text { VGM ID 56 és } \\
\text { Calderoni-taneszköz }\end{array}$ & Göcseji Múzeum & Korányi G. Tamás \\
\hline $1878-1884$ & $\begin{array}{l}\text { VGM ID 158 } \\
\text { (Toronyi Bence) }\end{array}$ \\
\hline $1885-1887$ & & $\begin{array}{l}\text { VGM ID 99 } \\
\text { (Császi Tamás) }\end{array}$ & $\begin{array}{l}\text { VGM ID 107 (MFM, Érd) és } \\
\text { Korányi G. Tamás }\end{array}$ \\
\hline $1905-1909$ & & & \\
\hline
\end{tabular}

Nélkülük ez a tanulmány sem készülhetett volna el.

\section{Irodalom}

Fodor Ferenc 2006. A magyar földrajztudomány története, MTA Földrajztudományi Kutatóintézet, Budapest, p. 820

Magidovics, Ioszif Petrovics 1961. A földrajzi felfedezések története, Gondolat Kiadó, Budapest. 877p

Márton Mátyás 2010a. Hunfalvy János és eddig ismeretlen glóbuszai. I. rész, Geodézia és Kartográfia 62. évf., 5. szám, pp. 22-29.

Márton Mátyás 2010b. Hunfalvy János és eddig ismeretlen glóbuszai. II. rész, Geodézia és Kartográfia 62. évf., 6. szám, pp. 12-16.

Márton Mátyás 2011. Új Hunfalvy-Felkl földgömb., Geodézia és Kartográfia 63. évf., 2. szám, pp. 10-11.

Márton Mátyás - Toronyi Bence 2020. Az elsô magyar nyelvú Felkl-glóbusz 1855-ben és megalkotói Geodézia és Kartográfia 72. évf., 4. szám, pp. 20-28.

MTA Alm. 1892. Magyar Tud. Akadémiai Almanach, Polgári és Csillagászati Naptárral MDCCCXCII-re. Kiadja a Magyar Tud. Akadémia, Budapest, 1892, p. 216

Mucha, Ludvík 1985. Der tschechische Globenmacher Jan Felkl. Der Globenfreund Nr. 33/34, Wien, pp. 122-142. A tagok munkálatai: Gönczy Pál pp. 136-138.

Novotná, Eva 2017. Jan Felkl \& syn továrna na glóby / Jan Felkl \& Son a GlobeMaking Factory, Univerzita Karlova, Prirodovedecká Fakulta, Praha, p. 184

Plihál Katalin 2016. Nyomtatott magyar földés éggömbök 1840-1990 Zrínyi Kiadó, Budapest, p. 232

Szinnyei József 1894. Magyar írók élete és munkái, 3. kötet. Gönczy Pál pp. 1360-1367. Hornyánszky Viktor, Budapest, p. 1582

Virtuális Glóbuszok Múzeuma 2007-ELTE Térképtudományi és Geoinformatikai Intézet, Budapest http://terkeptar.elte.hu/vgm vagy http://vgm.elte.hu, Utolsó elérés: 2021 . október 04.

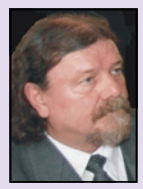

Dr. Márton Mátyás professor emeritus

ELTE Térképtudományi és Geoinformatikai Intézet matyi@map.elte.hu

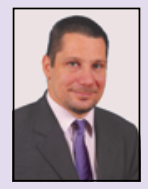

\section{Dr. Toronyi \\ Bence adjunktus}

Budapesti Múszaki és Gazdaságtudományi Egyetem, Építōmérnöki Kar, Általános és Felsôgeodézia Tanszék toronyi.bence@emk.bme.hu 